\title{
Innovation of Natural Orchid Cultivation Technology for Tourism Development in Banyunganti Hamlet, Jatimulyo Village, Girimulyo Sub-District, Kulon Progo District, Yogyakarta
}

\author{
Endang Semiarti ${ }^{1 *}$, Aziz Purwantoro², Ari Indrianto1, Aries Bagus Sasongko1, Oktaviana Herawati ${ }^{1}$, \\ Asri Fajar Milasari ${ }^{1}$ \\ 1) Faculty of Biology, Universitas Gadjah Mada, Jl. Teknika Selatan, Sekip Utara, Bulaksumur, Yogyakarta 55281, Indonesia \\ 2) Faculty of Agriculture, Universitas Gadjah Mada, Jl. Flora, Bulaksumur, Yogyakarta, 55281
}

Submitted: 27 May 2020; Accepted: 06 November 2020; Published: 15 December 2020

\begin{abstract}
Orchid is the best tourism icon which focused on nature-based tourism development in Indonesia. Banyunganti Hamlet is one of the tourism villages in Kulon Progo which has a high diversity of orchid species. Regarding this situation, guiding and assistance for villagers which is focused on the introduction of natural orchid species and its character, conventional propagation, and modern propagation by using household-scale tissue culture techniques (sowing seeds and planting) is important to give. The long-term goal for this activity was for empowering women in Dusun Banyunganti in line with the opening of the New Yogyakarta International Airport by the government.
\end{abstract}

Keywords: Orchid, Banyunganti Hamlet, Tour village, Kulon Progo district, Women's Group Orchid Farmer

Indonesia is a tropical country with mega biodiversity. One of them is the natural orchid which is scattered in almost all tropical rainforests, and one-sixth of the world's orchids population can be found in Indonesia. Some natural orchids are designated as superior areas, for example, Vanda tricolor var suavis is the superior orchid species of Sleman and Mount Merapi, Tiger orchids or Grammatophyllum scriptum endemic to Papua, Phalaenopsis amboinensis endemic orchid of Maluku, and others. Furthermore, orchid is a beautiful flowering ornamental plant and has a high economic value. It has the opportunity to be cultivated by the community to increase community income. It also can be expected as a local floriculture potency. Development in accordance with agroecological in this product will give better commercial value. As a result, Indonesian floriculture products able to compete at national and international levels.

The development of horticulture as a

\footnotetext{
*Corresponding author

Email: endsemi@ugm.ac.id

(C) 2020, J. Tropical Biodiversity Biotechnology (CC BY-SA 4.0)
}

biological resource needs to consider the EfSD concept. The existence of these plants must always be maintained, some are reproduced to be cultivated in order to maintain their existence in nature and others can be traded, even exported as a source of foreign exchange. In the EfSD concept, youngster and local communities must be equipped with soft skills and capability to multiply superior plants, even innovate with science and technology, invent new technologies with science and technology, so that continuity and quality of products can be guaranteed (Sudibyo, 2009). For example, the addition of peptone into a cultured medium could increase the efficiency and speed of seed germination of Phalaenopsis and Dendrobium orchids in vitro (Semiarti et al., 2014; Setiari et al., 2016; Mose et al., 2017; and Semiarti et al. 2017).

The Education for sustainable development program considers 3 pillars, namely economic sustainability, social justice, and environmental preservation including biodiversity and cultural diversity and culture (Sudibyo, 2009). The main road map of Community Service activities UGM 


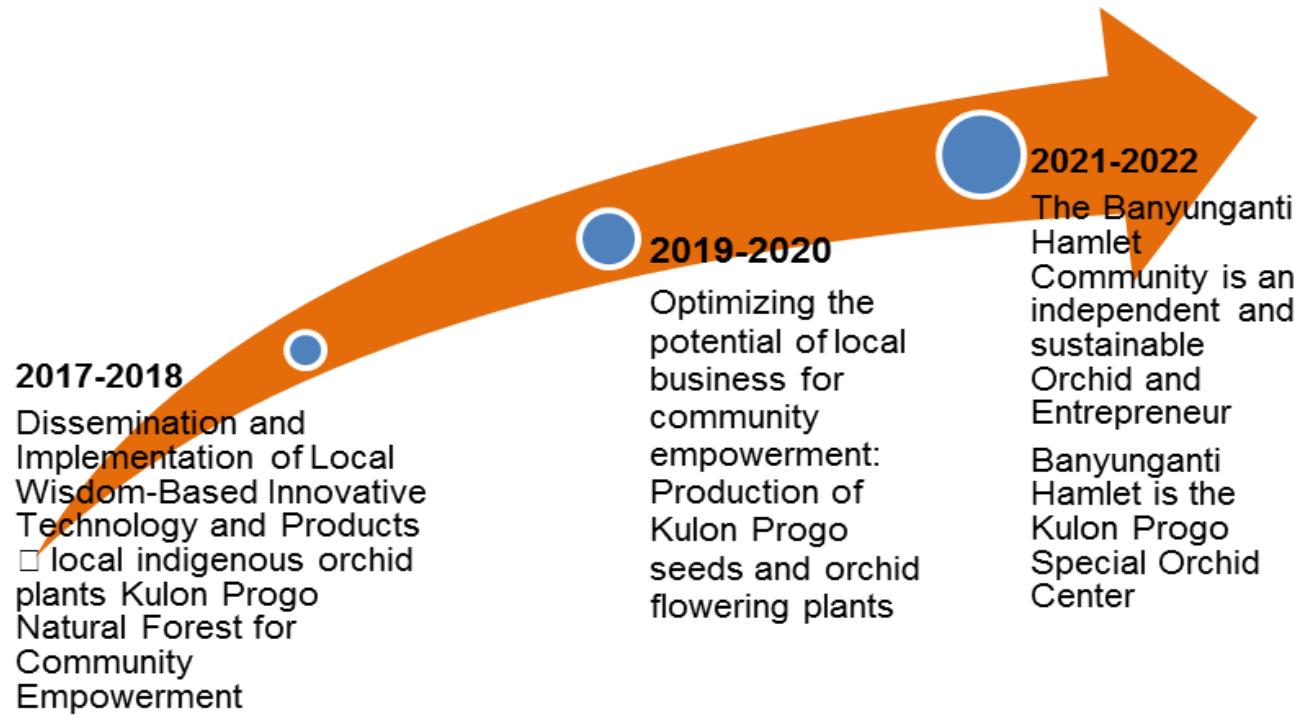

Figure 1. Road map of Community Service activities UGM Orchid Research Team.

Research Team for Multidisciplinary Orchids for the Establishment of Banyunganti Hamlet as Kulon Progo Orchid Center is as follow (Figure 1).

Banyunganti Hamlet is located in Jatimulyo Village, Girimulyo Sub-District, Kulon Progo District, Province of D.I. Yogyakarta. According to the Kulon Progo District Central Bureau of Statistics (2016), Jatimulyo Village has a land area of 16,2906 $\mathrm{km}^{2}$ with 12 hamlets. Geographically, Jatimulyo Village, Kulon Progo District has boundaries, namely, the northern boundary is Magelang Regency, Central Java Province; the southern boundary is the Indian Ocean; the western border is Purworejo Regency, Central Java Province; and the eastern boundary is Sleman and Bantul Regencies, D.I Province. Yogyakarta. The population distribution in Jatimulyo Village is 6,648 people with 3,276 male and 3,372 women (BPS, 2016).

Banyunganti Hamlet is one of the potential tourism areas in Yogyakarta. As a result, this place has several tourist attractions including Mudal River Park, Kembangsoka Waterfall, and Kedung Pedut Waterfall. The Banyunganti Hamlet community, which mostly has a livelihood as farmers, formed a tourism awareness group ("Kelompok Sadar Wisata"/ POKDARWIS) which made the Banyunganti Hamlet community increasingly understand tourism villages and realized the importance of developing their area as a tourist destination. As a tourist village, Banyunganti Hamlet requires its local characteristics. Banyunganti Hamlet has other tourism potentials that have not been developed to its full potential which can be used as a local characteristic of natural orchids that are native to the natural forest of Banyunganti Hamlet.

Based on the exploration research conducted by the Biology Orchid Study Club (BiOSC), Banyunganti Hamlet has a high diversity of orchids.
There are 23 species of natural orchids found in Banyunganti Hamlet of which the most common are Spathoglotis plicata, Dendrobium crumenatum, Arundina graminifolia, Cymbidium bicolor, and Acriopsis liliifolia (Figure 2). Unfortunately, the Banyunganti Hamlet community has not utilized the orchids as a regional characteristic due to a lack of public understanding of the important values and utilization of orchid's potentials. The introduction of orchids and their potential has been initiated through the Community Creativity Program for Community Service entitled "ANGGUN AYU Orchid of Banyunganti Hamlet: Development of the Forest Orchid Park" as a Means of Edutourism by students of the Faculty of Biology, Faculty of Cultural Sciences and the Faculty of Forestry. In addition, the community of Banyunganti Jatimulyo Village has also introduced a simple method of orchid cultivation through a grant from the Directorate of Community Service UGM with an Education for Sustainable Development (EfSD)based community service program scheme funded by the UGM BPPTNBH in 2017, and community groups have formed orchid lover.

Even though orchid farmer groups have been formed, only a few were interested in orchid entrepreneurship as a source of family income. Therefore, UGM orchid research team initiates the application of research results on in vitro and ex vitro orchid cultivation (Semiarti et al., 2014; Setiari et al., 2016; Mose et al., 2017; and Semiarti et al., 2017) to educate local people in Banyunganti Hamlet and innovate it with appropriate technology to help the community grow seeds, grow plants, and accelerate flowering induction in Kulon Progo native orchid plants. As the Orchid Education Center, the Faculty of Biology has played an active role in the Tri Dharma Perguruan Tinggi activities in the field of engineering. The research result of lecturers in the 


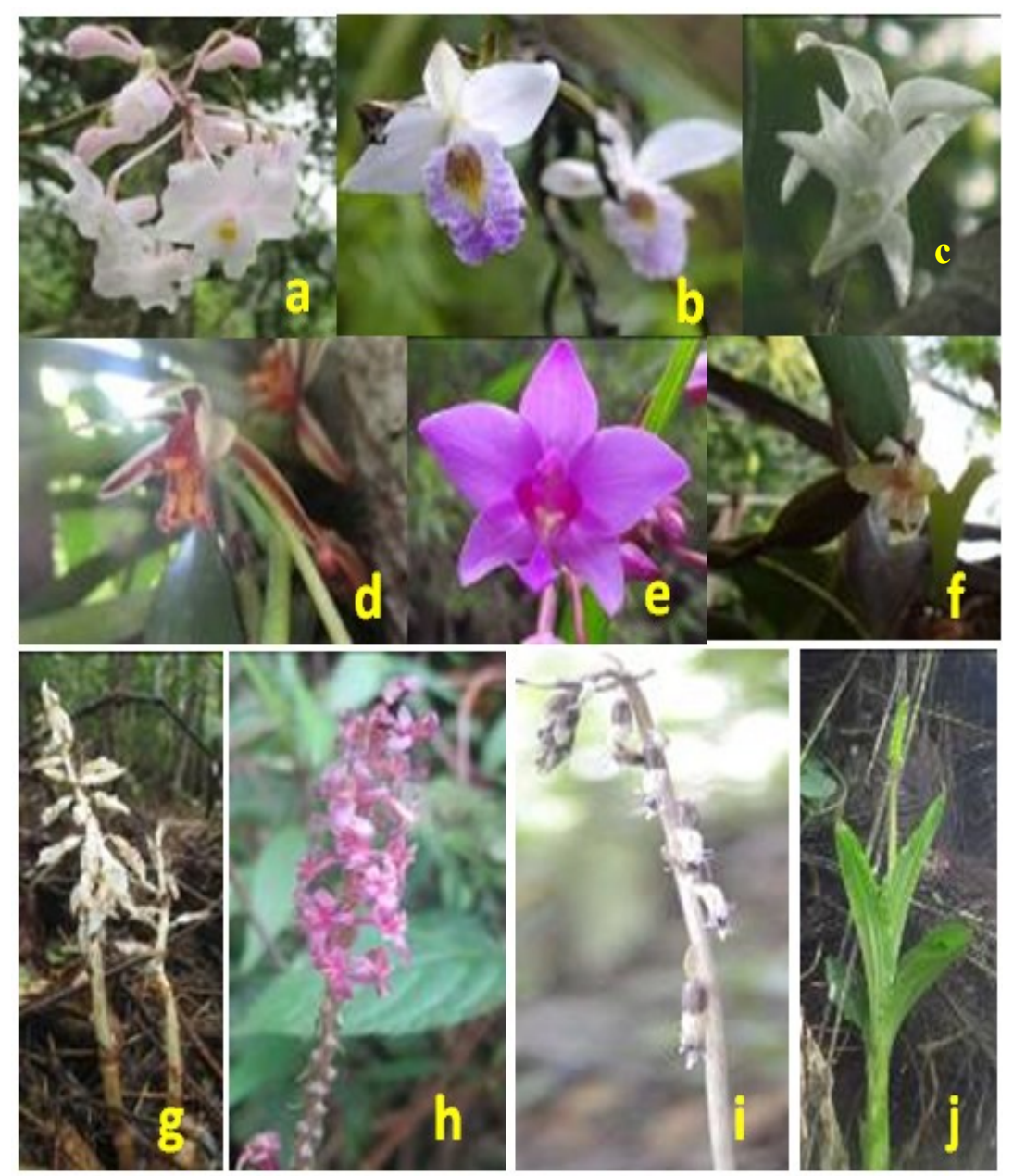

Figure 2. Orchid diversity in Banyunganti Hamlet. Epiphytic orchid (a-f). A.) Dendrobium mutabile, B.) Arundina graminifolia, C.) Dendrobium crumenatum. D.) Cymbidium bicolor, E.) Spathoglottis plicata, F.) Flickingeria fimbriata. Terrestrial orchids (g-h). G.) Epipogium roseum, H.) Malaxis kobi, I.) Stereosandra javanica, J.) Dienia ophrydis (After Wardhana, 2015).

orchid works have been published in popular media (newspapers and Facebook) and in national and international journals. Furthermore, some effective and efficient technologies for orchid propagation, prevention of pests and diseases, and induction of orchid flowering, which has been partially applied to the community, especially in collaboration with the Indonesian and National Provinces Orchid Society of Indonesia have been conducted as the Center of Excellent (CoE) of Orchids in Indonesia.

There were four main objectives for the community service, such as (1) increasing the knowledge and skills of Banyunganti Hamlet community about orchid cultivation techniques, especially the typical orchids of Kulon Progo District with the implementation of Appropriate Technology programs; (2) Facilitating lecturers and students of the Faculty of Biology and the Faculty of Agriculture UGM in mentoring and developing entrepreneurial programs and conservation of orchid biodiversity in Jatimulyo Village based on Appropriate Technology; (3) Realizing the collaboration between the people of the Banyunganti Hamlet, the Jatimulyo Village Government, UGM, the Indonesian Orchid Association of DIY Province, and the Study Group of the BiOSC students of the Faculty of Biology for the development of sustainable orchids in Banyunganti Hamlet; and (4) to increase the income of Banyunganti Hamlet community with sustainable orchid entrepreneurship.

The Empowering activity was held for 7 months, from May 2018 to October 2018. Training and education on orchid were carried out in the Banyunganti Hamlet, Jatimulyo Village, Girimulyo, Kulon Progo, D.I. Yogyakarta. The activities were divided into pre-implemented and implemented programs. Pre-implemented activity was held by intensive discussion and observation to determine the location, time, and programs. The discussion was an initial activity carried out with the aim of finalizing the idea that was initiated, namely conducting training and empowerment of the Banyunganti hamlet community with the theme of applying appropriate technology the results of research for the community to cultivate orchids. This is done to find the potential that exists in the hamlet in the form of potential cultural results, as 
well as natural resources, in this case, the natural potential of forest orchids and other carrying capacity as a destination that supports the development of tourism in the region such as rivers, waterfalls, and forest area. In addition, this observation activity also aims to obtain information about community interests and the problems they face in terms of developing potential and carrying capacity in the area. This activity is expected to provide a general description of what will be done in the next stage in developing the potential that exists in the area in the form of training and community empowerment regarding orchid cultivation in Banyunganti Hamlet.

Moreover, the implementation program began with the management of permits and raising cooperation with related parties. Furthermore, the making of leaflets, posters, and banners will be installed in strategic locations so that they are easily accessible by the community. In addition, the making of discussion materials will be carried out through PowerPoint slides, guidebooks, and CDs, as well as preparation of facilities and infrastructure for orchid cultivation and entrepreneurship. Theories and practices that will be given to the community include how to cross orchid flowers to produce fruit and seeds, planting orchid seeds in vitro, transferring bottle orchid seeds to pots, and maintaining orchid plants in demonstration plots and the natural forest of Banyunganti Hamlet.

There are eight orchid's training programs that were implemented to provide supplies to local people to become successful orchid farmers, especially for the development of Banyunganti orchids and tips on successful orchid entrepreneurship (Table 1).

From all training programs were given to the Women Orchid Farmers of Banyunganti Hamlet, it was seen that the participants were very enthusiastic in participating in these programs, and had followed up by trying it out on their own in groups many times at the head of the Banyunganti hamlet's house. This is very positive because technology will be mastered well if it has been carried out many times and coupled with various innovations tailored to the conditions in the field.

In addition, men have worked together to create a simple greenhouse for their orchid house. Orchid seedlings were transferred from the bottle into community pots (compot) and adult plants as

Table 1. The Orchid Training Program is based on Appropriate Technology that was given to the Group of Women Orchid Farmers of Banyunganti Hamlet.

\begin{tabular}{lllll}
\hline No. & Training Programs & Objectives & Outputs \\
\hline 1 & Introduction of Orchid & The community can practice the care of Some orchid breeders, \\
& $\begin{array}{l}\text { Parental and the Cross } \\
\text { Technique. }\end{array}$ & the pontential of orchids in the Banyuganti production. & \\
& Hamlet.
\end{tabular}

2. $\quad$ Making sterile orchid in vitro People can prepare sterile medium for in vitro culture medium. orchid cultivation on a household scale.

$3 \quad$ In vitro seed plantation.

People can germinate orchid seeds in vitro on a household scale.

4 In vitro subculture/ People can subculture orchid plantlets in vitro overplanting. on a household scale.

$5 \quad$ Hydroponic and Aeroponic Orchid Cultivation Training.

Local people can practice directly the installation of aeroponic and hydroponic orchid planting plants which are guided directly by agricultural experts.

6 Orchid Entrepreneurship.

Local people know about the tips and tricks in building a business by looking at the potential of the Banyunganti Hamlet.

$7 \quad$ Nuance Orchids Souvenir

Women Farmers Group Banyunganti Orchids can make nuanced souvenir trinkets orchid: hijab painting, orchid brooches, key holders.

Medium in vitro ready to use.

Some orchid seedlings production.

Orchid seedlings in bottles.

Hydroponic and aeroponic orchids set by local people of Banyunganti Hamlet.

Tips for successful orchid entrepreneurs.

Hijab painting, orchid brooches, key holders. online shop, instagram, youtoube. 
parental for breeding, as well as juvenile plants. So that it is expected that with continuous assistance from the Orchid Team of the Faculty of Biology UGM, the effort to establish Banyunganti Hamlet as the center of orchids in Kulon Progo can be realized.

In the long term, the program to produce and maintain the original orchid plant of Jatimulyo Village Natural Forest in a pilot plot or simple orchid house in Banyunganti Hamlet and ecotourism in "Taman Sungai Mudal" Park, can be equipped with orchid tourism facilities, orchid-nuanced souvenir shops, and online promotion systems will increase local orchid products typical of the Banyunganti Hamlet Forest, Jatimulyo Village and "Taman Sungai Mudal" Ecotourism by optimizing Orchid Masterplan demonstration and householdscale Laboratory, Kulon Progo forest orchid collection in its natural habitat for Orchid Tourism for the community.

Appropriate technology-based community empowerment activities from the results of orchid research implemented in Banyunganti Hamlet, Jatimulyo Village, Kulon Progo District have produced 8 programs that are continuously being developed by the Banyunganti Hamlet Women's Farmers Group. Intensive assistance needs to be carried out from the Orchid Team of the Faculty of Biology UGM, Indonesian Orchid Society Province of Yogyakarta, and the Regional Government of Kulon Progo Regency to support the sustainability of this activity so that the community can develop orchid tourism in their area independently and sustainably. To foster the interest of local people in developing orchid agribusiness in their area seriously, it is necessary to provide assistance from the government to complete the infrastructure and make a simple plant tissue culture laboratory to continuously grow plants and directly support "Bela_Beli Kulon Progo" and Yogyakarta International Air Port (YIA).

\section{ACKNOWLEDGMENTS}

We would like to thank the Indonesian Orchid Society Province Yogyakarta (PAI DIY), Biology Orchid Study Club (BiOSC), Faculty of Biology UGM Leaders for kindly supporting this work. This work is supported by the agreement assigning the implementation of Community Service Program Development based on the use of research results and the application of UGM Appropriate Technology Year 2018 number: 669/DIT.PM/2018 dated April 19, 2018, to ES, AP, and AI.

\section{REFERENCES}

BPS. (2016). Kulon Progo in number PT Pohon Cahaya. Yogyakarta

Mose W, Indrianto A, Purwantoro A, Semiarti E. (2017). The Influence of Thidiazuron on Direct Somatic Embryo Formation from Various Types of Explant in Phalaenopsis amabilis (L.) Blume Orchid. Hayati journal of Biosciences. 24: 201-205

Semiarti E., Setiari N., Astutiningrum W.D., Nurliana S., Mose W. (2017).The Effect of Peptone on Embryo Development of Orchid During in vitro Culture. AIP Proceeding of the 1st International Conference on Tropical Agriculture.pp.85-93.

Setiari N., Purwantoro A., Moeljopawiro S., Semiarti E. (2016). Peptone and Tomato Extract Induced Early Stage of Embryo Development of Dendrobium phalaenopsis Orchid. Journal of Tropical Biodiversity and Biotechnology. 1 (2): 77-84.

Semiarti E., Purwantoro A., Indrianto A. (2014). In vitro culture of orchids: The Roles of Class-1 KNOX Gene in Shoot Development. Journal of Biological Researches. 20: 18-27

Sudibyo, R.S. (2009). Sosialisasi Pendidikan untuk Pengembangan Berkelanjutan. [Education Dissemination for Sustainable Development]. Universitas Gadjah Mada.

Wardhana, H. (2015). Cantiknya Anggrek Pegunungan Menoreh [Beautiful Menoreh MountainsOrchids]. https:// $\mathrm{w} w \mathrm{w} \cdot \mathrm{k}$ o m p a s i a $\mathrm{na}$. c o m/ wardhanahendra/5516ebb0a333114977ba7e39 / cantiknya-anggrek-pegunungan-menoreh. Accessed on 3 November 2018 at 10.00 PM. 